\title{
The Ontological Status of 'The Living Dead' in Post Modern African: A Discourse in Existential Metaphysics
}

\author{
Nelson Udoka Ukwamedua \\ http://dx.doi./org/10.4314/ujah.v19i1.2
}

\section{Abstract}

This paper re-examines the place of the ancestors in post-modern Africa societies. It critically analyses the ontological status of the 'living-dead' in pre-colonial Africa society. This is predicated on the incursions/advent of proselytizing religions, nay Christianity and Islam and the force and pace of globalization. It is the contention of this paper that since these religions cum globalization have a lot of converts in Africa, little or no regard is now been paid to the ancestors. This is because most of the converts prefer their new relationships (religion and globalization) instead of venerating their departed, which they now see as belittling and fetish. On the other hand, the civilizing tendencies of Asia and the West, particularly the globalizing forces, like the media and ICT, fostered this high disregard for the ancestors. This paper concludes that since the living don't even reflect the moral sanctity Africa was once known for, as a result of avarice, consumerism, materialism plus the alluring strings of globalization, the so-called 'moral paragon' should be allowed to really rest in peace.

Key words: African religion, ancestors, worship, globalization, post-colonial, morality. 


\section{Introduction}

"In the beginning it was religion, and in the end it should be all religion (Abe 2004, 3). Actually, men took off from religion, march along with religion and arrive at religion in their daily engagement (Ejiofor 1973, 63). Arising from the foregoing, African people demonstrate their religion with mark of honour or reverence for the supersensible world. Thus, this demonstration serves as a schema of religious ceremony to the Supreme Being through the divinities or ancestors. African people possess a rich religious heritage, which they display in communion with the higher beings. This religious observance is pivotal to them and they are always with them. Thus, Africans are not bereft of religion. Africans have always acknowledged their ancestors by preserving their cultural creations and belief in celebrating and performing rituals. As a matter of fact, we have benefited immensely from the various works of scholars such as E.B. Idowu, J.O. Awolalu, Ade P. Dopamu, J.S. Mbiti, among others.

They have all done invaluable works on African religion with particular regard to the ancestors. Idowu, for instance, observed that ancestors in African religion are the departed members of the families on earth (Idowu 1991, 179). Awolalu supports what Idowu posited that the ancestors are deceased spirits who stand in close relation to the family as well as have enhanced prestige (Awolalu 1979, 63). In their various works, it was discovered that African ancestors have become commonplace. But none of these scholars has touched on the present positions of the ancestors especially in this stage of technology coupled with multifarious problems in the post-colonial/modern environment. It is the intention of this paper to analyse the ontological status of these ancestors, especially against the backdrop of imposing 
variables and dynamic existential realities in post-modern African societies.

\section{Conceptualizing African Ancestors}

The root of religion is the absolute dependence of human beings on supernatural powers, capable of aiding them in time of trouble and distress. This underscores that fact that Africans believe that they can commune with their ancestors, who have enhanced powers associated with their newly acquired status and particularly as intermediaries between man and the Supreme Being(Smith 1960, 63). This specifically informs the belief in the ancestors and their corresponding relevance. Ancestors are the departed spirits who are honoured as a result of their long-good, spectacular and extra-ordinary lives on earth and at death are being venerated. Thus, Idowu describes ancestors as:

...the deceased who are truly members of the families on earth; but they are no longer of the same fleshy order as those who are still living in the flesh on earth. They are closely related to this world; but are no longer ordinary mortals. Because they have crossed the borderland between this world and the supersensible world entering and living in the latter, they have become freed from the restrictions imposed by the physical world. They can now come to abide with their fold on earth invisibly, to aid or hinder them to promote prosperity or cause adversity(Idowu, 184).

Supporting this view, Kwame Gyekye avers that the ancestors are certain individuals of the past generations of a lineage who are said to have distinguished themselves in many ways and in particular, those who have led virtuous and exemplary lives worthy of emulation by succeeding generations of the lineage. Such 
individual according to Gyekye are regarded as moral paragons(Gyekye 1996, 162).Udo Etuk also opines that the ancestors are revered consequent upon their affairs of their lineage and are believed to have a great deal of influence over their lineage and siblings. They also play a great intermediary role between the physical and spiritual world (Etuk 2002, 33).

The ancestors are believed to be quite near and present at every occasion, only a thin veil separates them from the living (Etuk 33). In fact, the ancestors even at death can see, hear, feel and express emotions (Awolalu 62). Besides, ancestors are able to see and observe what is happening on earth, and they maintain the greatest interest in the affairs of man, most especially those of their immediate family. No wonder, Mbiti refers to them as the "living dead" who keep constant and healthy communion with the living. Ancestors have various names from locality to locality. The Yorubas call them Baba nla or Babajide -the great fathers; the Igbo call them Ndichie- those of old, the Igalas call them Okwoikwo meaning the great parents (males and females), the Urhobo call them Eriuwi meaning the dead fathers and mothers, the Ewe and Fon refer to them as Tovodu, and the Akan people of Ghana call them Nsamanfo, or Nananom Nsamoanfo (Gyekye, 162; Mbiti 1992, 143; Awolalu, and Dopamu 1979, 247).

Generally in Africa, only men are seen as ancestors except in some areas like among the Igalas and Urhobos. Although, during sacrifices and pouring of libations, when homage is paid and prayers are said; it is only those within living memory that are mentioned. However, it is believed that those not remembered by name, can still share in the offerings made to the dead. In the African belief system, the family is made up of both the living members and the ancestors. The ancestors are still present, watching over the household and the property of the family. They 
are the powerful part of the clan, maintaining a close link between the world of men and the spirit world. They are believed to be interested in the welfare of their living descendant. They even exercise protection and discipline any erring member of the living belonging to their clan.

Thus they are guidance of family affairs, traditions, customs, ethics \& morality, health and fertility. They punish cases of incest, stealing, adultery, bearing false witness and other moral vices, they are regarded as elders of the family and they are reincarnated into the family (Amponsah 1974, 85). Even, when a woman is being given out in marriage, libation is poured to the ancestors. Since ancestors are no longer visible in the physical sense, Africans attributed some element of spiritual powers to them. Their power is derived from the Supreme Being but used independently of him. Such powers are believed to be for good or for evil. It is believed that witches and sorcerers cannot harm a man and bad medicine cannot have effect on him if his ancestors are not asleep. That is why the Yorubas say to their ancestors Baba mi ma sun lorun meaning my father, do not sleep in heaven'. He is expected to be vigilant, watching over the living. If they dream of a dead relative, it is believed is a proof of the presence of the ancestor.

The ancestors can also influence rainfall, good harvest, promote prosperity etc. misfortunes like drought, famine and destructive calamities are also attributed to them. Misfortunes however belong to those who break their taboos. Africans ascertain from time to time the will of the ancestors through the oracle. They secure their help and appease them when they are provoked to anger. It is essential that the living be in good terms with the ancestors and even give them more regard then they deserve while they lived in physical form. This is why Africans usually do not go 
to sleep with their pots empty. In fact, food is always left outside at night for any visiting ancestor. Water is not poured away at night without first announcing it so that any ancestor around may not be injured. When people drink wine or hot drinks, they pour a little on the ground for the ancestors. All these are to acknowledge and strengthen the interpersonal relationship between the living and the dead. Despite this closeness, ordinary people cannot see the ancestor. It is only those who possess special power or medicine that can notice their presence. The ancestors functions as a cohesive factor in some communities. For instance Amponsah says, "... among the Ashanti, the sacred golden stool which is the ancestral symbol is regarded as the shrine and symbol of the national soul. Which means that, in it, the whole nation is united as of one 'soul"' (Amponsahn1973, 86).

Qualification of African Ancestors

To the African, death is not the end of life, it is a continuum, as such the African dead are not totally cut-off form their descendants. Actually, the African dead have an endless fellowship with the living in the community. With this description, it thus informs us about Idowu's concept of partial reincarnation indicating that the Baba nla of the family never dies. Rather, death had given him more power and prestige to oversee man's mundane activities and at the same time, he reincarnates(Idowu 1996, 207). The qualifications of the ancestors are; those who have led a good life, those who lived to a ripe old age, those who died 'good death' and accorded full burial rites(Awolalu and Dopamu, 174). For this reason, to the African, burial is very significant and symbolic. Thus, burial has theological, environmental and spiritual imports. Theologically, proper burial is the requirement for admission into the communion of the ancestors. People who are not properly buried revolve around. But when the deceased are 
buried properly, both the living and the dead live in peace. This burial goes beyond the physical realm; it has eschatological implication for the people also. It was said by Idowu that Africans when venerating the ancestors, go beyond their boundaries. This propels observers to say that ancestors are worshipped (Idowu, 207; Awolalu, 63). Also, Dopamu expressing this view on the African ancestors posits that ancestral veneration cannot be separated from worship (Smith 2005).

Contrary to these opinions, ancestors are not worshipped rather they are revered as a result of their great feat and influence on the affairs of their descendants and their cordial relationship with the supersensible world. Gyekye asserts that veneration does not amount to worship, rather it is an African social behaviour bequeathed to the dead (Gyekye, 163).It is a manifestation of filial piety or an unbroken relationship between the parent who has departed from this world and the offspring who are still here(Idowu, 207; Awolalu, 63). Furthermore, ancestors live beyond the mundane and are subsequently approached by their siblings. This appreciation of the ancestors by their siblings is demonstrated in reverence. Agreeably, ancestors are included in the religious hierarchy of the Africans and are charged with the responsibility of acting as intermediaries between men and the supersensible world(Awolalu and Dopamu, 274).

Therefore, they are not restricted to their mundane or social environment but have great flair for religious issues. Factually, ancestors maintain healthy and uninterrupted relationship with their immediate families, which enable them to give consideration to human feelings. They get in touch with their siblings often and participate in everyday activities. Admittedly, the ancestors are constantly invoked and they are not unaware of the actions, intent and feelings of their descendants who on their behalf are the 
temporary caretakers of lineage and prosperity(Shorter 1969, 29). This also readily makes the ancestors to be conscious of their importance as central to the sustenance of their descendants. Without an equivocation, they help to project the yearnings of potentials possessed by the ancestors; they are also capable of exploring these qualities against those still alive(Idowu, 207).

Sometimes, in order to maintain the relationships, the spiritual head carries out rituals and cannot take food in religious gathering or drink without first and foremost throwing out a morsel or pouring libation to the ancestors(Etuk, 33). Likewise, it is believed among Africans that it is an abomination to empty their pots at night so that when the ancestors come, they can have a share from the remnant. To reiterate their relevance, some of these ancestors are celebrated with great festivals. For instance, in Yoruba religion, these ancestors include: Egungun and Oro and they play prominent role in the socio-cultural undertaking of the people(Idowu, 207).

Idowu is apposite when he asserts that those who depart from this physical earth continue in existence in the world of the immaterial and actively involved with those who are still here (Idowu, 207). Also, there are communal ceremonies in respect of African dead. Among them are Mmиo in Igbo land, and Adae ceremony among the Akan(Awolalu and Dopamu,, 276). In addition we have $U d a$ in Ekpoma, Obazu in Aoma both in Edo state (land). During these festivals, animal offerings are made to the ancestors and they are followed by prayers, and the praise names of the ancestors are chanted.

\section{Veneration of Ancestor among Africans}

These African ancestors were heroes in their lifetime. They had positively influenced lives, affected development and liberated 
people from imperialism. Oftentimes, they could be remembered by building schools or erecting markets in their honour. Ancestors are also referred to as "moral paragons" because, they uphold morality and they are custodians of traditional morality. Awolalu and Dopamu capture their strong influence in the society this when they remarked that belief in Ancestors supplies sanction for public morality.

They are the guardians of traditional morality. They, therefore, demand a high sense of respect for the traditional law and custom. The living must live as they have lived. It is believed that just as the living parents have power to punish disobedience in the youth or dereliction of filial duties so also the neglected or offended ancestors can punish their offspring for moral offences, and they can bring disaster upon the whole family(Awolalu and Dopamu, 276).In several cases, the ancestors also condemn and punish those who commit atrocities, such as murder, stealing, witchcraft, adultery, false oath, hatred, incest, bearing false witness among others. In fact, the communal ceremonies unify and consolidate the society, because it is generally believed that when people converge in public gathering, they express their feelings, emotions, even sentiments through singing, dancing, clapping of hands and expression of joy.

Undoubtedly, this act of public gathering in which people or community meet to honour their ancestors is called festival. Festival promotes social solidarity, communal order and hopes of people are kept alive. Socially speaking, festivals virtually bring together whole community and provide an occasion for the renewal of strained relationship among of the community. Awolalu and Dopamu support this when they posited that, the coming together of the people is re-enacted and many people for the first time in the year meet on festival occasions. Men and women are 
brought together in one crowd and there is usually a sort of social re-union(Awolalu and Dopamu, 149).

Through festivals, the life of community is revived. People are entertained and their tensions find an outlet. As a matter of fact, human life needs some important festivals to give both solemnity and laughter. The celebration of the festival in honour of the ancestors is wholly engulfed with grandeur of rituals and people come out in their best attires and feast together. It is equivalent of Christmas. The chief priest and the head of the community would sit in state and receive homage from the sub chiefs and subjects. The people see festival as the social safeguard of the basic needs of their existence and of the basic relations that make up their social order: land, rain, bodily health, the family, the community(Quarcoopome 1987, 88). Largely, the people during this time help to foster the sense of identity and belongingness as well as solidarity. These are the integrative and cohesive factors upon which the survival and continuity of the community depends. Religiously, the festivals welcome the ancestral spirits to human societies and renew their relationship. The religious values are repeated through communal festivals.

To this end, Mbiti helps a great deal in summarizing the religious relevance in this paradigm when he said that, people seize such occasion to solicit blessings from God or the departed, and there is a general feeling that the visible and the invisible worlds co-exist for the benefits of man who is at their centre. Rituals and festivals are religious ways of implementing the values and beliefs of society(Mbiti 1991, 143). Sequel to the above, ancestral celebrations are important in order to reaffirm and consolidate these religious values which are inherent and deep rooted among the people. To this end, celebration of the ancestors is a commonplace rehearsal in African Religion. Thus, the celebration 
of the ancestors is a mark of honour and remembrance as well as the invocation of the African dead. Ancestral veneration aids adherents spiritually, especially as regards healthy and cordial relationship with the spirit world. Ancestral veneration is performed either annually, bi-annually, monthly, bi-monthly or anytime especially at the dictate of the oracle divinity. Ancestral veneration in African Religion is conducted by either the heads of the immediate families, priest, priestess or clan heads as the occasion demands.

\section{The Paradox of Ancestor Veneration in Post Modern Africa}

From the foregoing, it is apparent that African ancestors are the spirits of the departed who are remembered and honoured with great festivals. They participate in virtually all that take place in their immediate families in particular and the communities in general. They gained a high and spiritual status endowed with powers, which the living does not possess. Contrary to these positions, it is expedient to state that majority of the ancestors are not humane to their subjects. It is an obvious fact that the ancestors were despotic during their lifetime. This was obvious when the first missionaries came to plant Christianity in Africa.

They worked through the Obas and others to forcefully convert their subjects because the missionaries believed that African Kings wielded more power to coerce their subjects. Some of the head chiefs "were known to have been tyrannical rulers who led morally unworthy lives. From the days when human sacrifice was practiced - always with the direct or at least the indirect involvement of the chief" (Gyekye, 163).Gyekye adds that the respect accorded the living chiefs today is not necessary respect for the morally virtuous lives of living chiefs. Some chiefs in Africa today are morally corrupt. Meanwhile, the ancestors are referred to 
as "moral paragons" in which case, they are custodians of public and traditional morality in their community.

However, it is no longer true today that they are still virtuous. They are morally bankrupt as a result of the fact that some moral problems such as stealing, incest, sorcery, witchcraft, killings, maiming, disobedience, adultery, false oath, hatred and lots of others have assumed dangerous and unprecedented dimension. These moral problems which suppose to attract sanctions by the ancestors are allowed to soar and remained unchecked. In point of fact, the ancestors are today blind to the endless challenge Africans face in the society. Looking at the role of ancestors, it is certain that much power has been given to them; as such, we expect much from them. Today, the opposite is the case, because our lives are dependent on multifarious variables. These variables are both endogenous and exogenous in nature. It is endogenous in the sense that the problems we cause for ourselves, emanating from the family or head of the family cannot be handled by the ancestors. The fact is that the ancestors cannot provide for all our material well-being. Similarly, exogenous problems, emanating from bad leadership, harsh economic reforms, political uprisings, social crises, among others, cannot be solved by the ancestors. Even when the so-called living are caught in the intractable web of these problems, they go scot-free without sanction from their "moral paragon".

In African religious belief, the ancestors are consulted through the oracle before any function is performed. Lately, human beings have taken over the position of the ancestors; they no longer consult the oracle so as to know the mind and choice of the ancestors concerning certain issues affecting the community. For instance, money is freely used in many communities to determine the next king of which the kingmakers are brought over and they 
speak their minds instead of the minds of ancestors. This appalling state of affairs would make a discerning mind to ask, where are the ancestors? If they are still the "living-dead", it means they are crying for justice, reinstatement and restoration.

That's why, one would be compelled to agree with Kofi Awoonor that: "The gods are crying, my father's gods are crying for a burial... for a final ritual... but they should build the fallen shrines have joined the dawn marchers singing their way towards Gethsemane...the gods cried, shedding ...the drink offering had dried up in the harmattan and the fetish priest is dressing up for the Easter service(Awoonor 2003, 312). These expressions reveal that the ancestors are handicapped and men have taken over their position hence they are screaming for a burial consequent upon their abandonment. This somewhat is aligning with the view of some scholars who contend that in Africa, it is a matter of 'man made God or gods'. These shades of scholars are of the view that some of the things Africans call gods are not gods. Therefore, there are only impression of gods created in man's mind, so varied are the gods and creeds which have been brought into being by playing on emotional arousal, increased suggestibility and abnormal phases of brain activity. Certainly, totally different beliefs can be and are created and maintained by the methods of indoctrination.

This lends credence to the fact that faith-healing, in both simple and sophisticated societies, also depend on the induction of emotional excitement to achieve the breakup of old behaviour patterns and the emergence of new ones. Man in diebusillis did worship the forces he could not understand and termed some of these, gods. By so doing, he used his imagination to imagine them into various shapes, shades, sizes and colour. There is no doubt that the cult of gods even priest-craft were as a result of imagination, which was improved through practice. Imagination 
brightens man's life, as it is not only a science, it is equally an art. In the opinion of Ogugua (2005), as a result of these, in the art of establishing deities, intelligent imaginative thinking was not lacking. Osborn (2003 VII) states: "imagination is the cornerstone of human behaviour; it is, without doubt, responsible for man's survival as an animal, and it has caused him, as a human being, to conquer the world.

It may well lead him to subdue the universe". It was the use of imagination that made the human animal remarkable. Imagination remains the pristine power of man. it is when the magnetic chord stretches from the mind that sympathetic agreement of ideas which flow in currents will go on to create a crucible of new and original ideas. By so doing, consciousness is stretched into boundless space, there it sees the beauty (of ideas and) in ideas; and bath in the sea of formless matter. On this, Lewis $(1975,29)$ states, "to be truly self-conscious is to be conscious of both the spiritual and divine and the mental and physical constitutions of the human being". Hence, Gyekye posits that there is no real justification for unrelenting strictness to all features of the received culture and heritage. The ancestors do not expect their offering to make changes in their legacy for times change (Gyekye, 166, Mbamara, 2005, 56). Albeit, judging from the magnitude and multifarious problems in the post colonial period of the African society, the place of the ancestors cannot be justified. Therefore, the ancestors should be made to perpetually rest in peace and be forgotten.

\section{Culmination Reflections}

Having extensively explored the African ancestors, their qualification, function, social and religious significance, coupled with their dilemma, it is appropriate to maintain that the ancestors 
can no longer occupy their hitherto pride of place. The current paradigms of the ancestors as well as their achievements indicate that they must be remembered, praised and celebrated, but cannot enjoy such powerful position and influence they once enjoyed. The post-independence terrain does not guarantee such a place anymore.

To this end, Kwame Gyekye states what ancestors are not in contemporary African society when he said that we must not expect them to bestow favour on their descendants. The post colonial problems of African clearly show that the ancestors cannot be helpful. The greatest reverence we, the descendants of the ancestors, can show to them is to let them rest in peace. This is because, in recent years, the sweeping wave of western globalization conveyed through western language- English and disseminated through global information communication technology, the internet as well as the counter penetration of western religion have completely eroded, destabilized and destroyed this virtuous culture of Africa. Nevertheless, one should not be oblivious of the fact that insipid alienation attends the contemporary African society in her social, economic, political, religious and cultural heritages. Unless measures are taken into consideration and issue properly put in context the pangs of African culture would ever remain in travail. Meaning that, globalization with its attendant effects of identity crisis and cultural alienation may become more intense.

Because without any iota of doubt, globalization has spread its tentacle throughout the world. Much erosion of the cultural traits of the people where globalization has been spread to is much devastating especially in Africa, which is so rich in culture as almost every facet of African culture being affected has become relegated, retarded and subsequently lost especially the system of 
ancestor worship. So, ontologically speaking the 'moral paragons' of the pre-modern African societies no longer have stake in the scheme of things and must be allowed to indeed finally rest in peace in their graves.

\author{
Nelson Udoka Ukwamedua \\ Department of Philosophy, \\ Veritas University Abuja \\ nelsonmedua@yahoo.co.uk
}

\title{
References
}

Abe, G.O. 2004. "Yahwism Tradition vis-à-vis African Culture: The Nigerian Milieu". Inaugural lecture series 1.Delivered at Adekunle Ajasin University, Akungba-Akoko.

Amponsah, K. 1974.Topics on West African traditional religionvolume. 1 Accra: McGraw-Hill FEP.

Awolalu, J.O. and Dopamu, P.A. 1979. West African traditional religion. Ibadan: Onibonje Press and Books Ltd.

Awolalu, J.O. 1979. Yoruba beliefs and sacrificial rites. London: Longman.

Awoonor, Kofi. 2003. "Easter Dawn" cited by Ogbu-U-Kalu After the Former Rains: Paradigm Shift in the Study of Cultural Identity and Christianity in Nigeria" in P. Ade Dopamu and E. Ade Odumuyiwa (eds.). Religion, science and culture. Ikenne-Remo: Olarotayo \& Co.

Ejiofor, L.U. 1974."Religion and a Healthy Political System". Nigerian Dialogue.1.1 (July).

Etuk, U. 2002.Religion and cultural identity. Ibadan: Hope Publications. 
Gyekye, Kwame. 1996. African Cultural Values: An Introduction. Accra: Sankofa Publishing Company.

Idowu, E.B. 1991. African traditional religion: A definition. London: Fountain Publications.

Idowu, E.B. 1996. Olodumare: God in Yoruba belief. Nigeria: Longman.

Lewis, S.H. 1975. Human consciousness. Evanston: North Western University press.

Mbamara, C.I.C. 2005. "Creation of deity in African clinical and social settings: an epistemological inquiry". Essence: International, interdisciplinary journal of philosophy (African Philosophy And Pathology of Godhood and traditionmalism. 234 - 63.

Mbiti, J.S. 1992. Introduction to African Religion and Philosophy. Nairobi: East African Educational Publishers.

Mbiti, J.S. 1991. Introduction to African Religion. USA: HEB.

Ogugua, P.I. 2005."Understanding deities in Igbo-African world: A religio-philosophical perspective". Essence: International, Interdisciplinary Journal of Philosophy (African Philosophy And Pathology of Godhood and traditionmalism). 2, $64-88$.

Osborn, A.F. 2003.Applied imagination: Principles and procedures of creative thinking. Nigeria: Improvement Pub. Quarcoopome, T.N.O. 1987. West African Traditional religion. Ibadan: African University Press.

Shorter, A. 1969."Conflicting attitudes to ancestor veneration in African". AFER. XI. 29.

Smith, A.P. 2005.Worship in African Religion. New York: Double Day.

Smith, E.W. 1960. African idea of God. London: Edinburgh House Press. 